\title{
The Assessment of the Neutrophil-lymphocyte Ratio and Platelet-lymphocyte Ratio in Dyslipidemic Obese Children
}

\author{
Dislipidemik Obez Çocuklarda Nötrofil Lenfosit Oranı ve Platelet \\ Lenfosit Oranının Değerlendirilmesi
}

\author{
(D) Tuğçe Damla Dilek¹, (D) Özlem Bostan Gayret¹, (D Suna Kılınç², (D Meltem Erol1, (D Özgül Yiğit¹, \\ (D) Fatih Mete ${ }^{1}$ \\ ${ }^{1}$ University of Health Sciences, Bağcllar Training and Research Hospital, Clinic of Pediatrics, İstanbul, Turkey \\ ${ }^{2}$ University of Health Sciences, Bağcılar Training and Research Hospital, Clinic of Pediatric Endocrinology, İstanbul, Turkey
}

Abstract

Objective: Childhood obesity is one of the most important children's health problems that is gradually increasing all over the world. Dyslipidemia which coexists with obesity is a risk factor for atherosclerotic diseases in adulthood. In this study, the usability of the neutrophil-lymphocyte ratio (NLR) and the platelet-lymphocyte ratio (PLR) in predicting dyslipidemia, a serious complication of obesity, in children were investigated.

Method: Two hundred and seven cases aged between 11-17 years who were diagnosed with obesity at the Pediatrics Clinic of our hospital and 50 cases with no disorders whose complete blood count was performed for routine purposes were retrospectively investigated. The genders, ages, and examination findings of the cases were recorded. In obese children, leukocyte, hemoglobin, platelet, mean platelet volume, neutrophil and lymphocyte levels were evaluated in the complete blood count performed at the first admission. The NLR and the PLR were calculated. Preprandial blood glucose and preprandial insulin, serum aminotransferase values, and the lipid profile were recorded.

Results: While dyslipidemia was determined in 99 (47.82\%) of 207 cases who were diagnosed with obesity, it was not determined in 108 (52.18\%) cases. The systolic blood pressure, diastolic blood pressure, and preprandial insulin level were higher in cases with dyslipidemia than the group without dyslipidemia. The PLR average of the dyslipidemic group was $112.75 \pm 39.11$, the PLR average of the non-dyslipidemic group was $104.78 \pm 31.38$, and the PLR average of the control group was $110.20 \pm 39.35$, and there was no statistically significant difference between the PLR averages of the groups $(p=0.353)$. The NLR average was $1.52 \pm 0.69$ in

\section{Öz}

\begin{abstract}
Amaç: Çocukluk çağı obezitesi tüm dünyada giderek artan en önemli çocuk sağlığı sorunlarından biridir. Obezite ile birlikte olan dislipidemi, erişkin dönemde aterosklerotik hastalıklar için bir risk faktörüdür $\mathrm{Bu}$ çalışmada çocuklarda, obezitenin ciddi bir komplikasyonu olan dislipidemiyi öngörmede nötrofil-lenfosit oranı (NLO) ve platelet-lenfosit oranının (PLO) kullanılabilirliğini araştırdık.
\end{abstract}

Yöntem: Hastanemiz Çocuk Sağlığı ve Hastalıkları Kliniği'nde obezite tanısı alan 11-17 yaş arası 207 olgu ve herhangi bir rahatsızlığı olmayıp rutin amaçlı tam kan tahlili yapılan 50 olgu retrospektif olarak incelendi. Olguların cinsiyetleri, yaşları, muayene bulguları kaydedildi. Obez çocuklarda ilk başvuruda alınan tam kan sayımında lökosit, hemoglobin, trombosit, ortalama trombosit hacmi, nötrofil ve lenfosit düzeyleri değerlendirildi. NLO ve PLO hesaplandı. Açlık kan şekeri ve açlık insülin, serum aminotransferaz değerleri ve lipid profili kaydedildi.

Bulgular: Obezite tanısı alan 207 olgunun 99'unda (\%47,82) dislipidemi saptanırken, 108 olguda $(\% 52,18)$ dislipidemi saptanmadı. Dislipidemi saptanan olguların sistolik kan basıncı, diastolik kan basıncı ve açlık insülin düzeyi dislipidemi olmayan gruptan daha yüksekti. Dislipidemik grubun PLO ortalaması $112,75 \pm 39,11$, dispidemik olmayan grubun PLO ortalaması 104,78 $\pm 31,38$, kontrol grubunun PLO ortalaması 110,20 $\pm 39,35$ olup grupların PLO ortalamaları arasında istatistiksel olarak anlamlı farklılık gözlenmemiş̧ir $(p=0,353)$. NLO ortalaması dislipidemik grupta $1,52 \pm 0,69$, dislipidemik olmayan grupta $1,66 \pm 0,81$, kontrol grubunda $1,72 \pm 1,26$ idi. Her üç grubun NLO ortalaması arasında istatistiksel olarak anlamlı farklılık gözlenmemiştir $(p=0,295)$.

Address for Correspondence: Özlem Bostan Gayret, University of Health Sciences, Bağcılar Training and Research Hospital, Clinic of Pediatrics, İstanbul, Turkey

E-mail: drozlemgayret@gmail.com ORCID: orcid.org/0000-0003-4121-8009 Received: 28.06.2019 Accepted: 01.08.2019

Cite this article as: Dilek TD, Gayret Bostan Ö, Kılınç S, Erol M, Yiğit Ö, Mete F. The Assessment of the Neutrophil-lymphocyte Ratio and Platelet-lymphocyte Ratio in Dyslipidemic Obese Children. Bagcilar Med Bull 2019;4(3):56-60

${ }^{\circ}$ Copyright 2019 by the Health Sciences University, Bagcilar Training and Research Hospital Bagcilar Medical Bulletin published by Galenos Publishing House. 


\section{Abstract}

the dyslipidemic group, $1.66 \pm 0.81$ in the non-dyslipidemic group, and $1.72 \pm 1.26$ in the control group. No statistically significant difference was observed between the NLR averages of all three groups $(p=0.295)$.

Conclusion: In this study, no relationship was determined between the PLR and NLR and dyslipidemia in obese children.

Keywords: Children, dyslipidemia, neutrophil-lymphocyte ratio, plateletlymphocyte ratio

\section{Öz}

Sonuç: Çalışmamızda obez çocuklarda PLO ve NLO ile dislipidemi arasında ilişki saptanmadı.

Anahtar kelimeler: Çocuk, dislipidemi, nötrofil-lenfosit oranı, plateletlenfosit oranı

\section{Introduction}

Obesity, which is an important cause of morbidity and mortality, is gradually rising in the young people $(1,2)$. Many health problems such as cardiovascular diseases, hypertension, type 2 diabetes, and fatty liver are associated with obesity (3).

Elevation of triglyceride (TG), LDL and total cholesterol values and a decrease in HDL cholesterol values in obese children cause an increase in the risk of cardiovascular diseases in childhood (4). Therefore, the early diagnosis and treatment of risk factors in obesity gains importance.

Recently, obesity is also known to be associated with immunological abnormalities (5). Inflammatory cells infiltrate adipose tissue in obese individuals, and these inflammatory cells and fat cells cause a low level of chronic systemic inflammation by producing cytokines $(2,6,7)$. The neutrophil-lymphocyte ratio (NLR) and plateletlymphocyte ratio (PLR), which are considered to be indicators of subclinical inflammation, are cheap and easily calculable haemogram parameters, and in recent years, their relationship with obesity and obesity-associated diseases has been investigated (8-13).

Complications of obesity in children are now better known. Therefore, the treatment and prevention of obesity have remained a problem that should be solved urgently. In this study, we investigated the usability of NLR and PLR, which are easy methods, in the prediction of the presence of dyslipidemia in obese children.

\section{Material and Methods}

Two hundred and seven cases, who were diagnosed with obesity upon applying to the outpatient clinic of our hospital pediatrics clinic between January 2017 and May 2017 and who were between 11-17 years of age, and 50 cases, who did not have any disorder and who underwent a complete blood test for routine purposes, were retrospectively examined. Children with the body mass index (BMI) determined to 95 percentiles and higher according to age and gender were considered as obese. By using height and weight measurements, the BMIs [weight $(\mathrm{kg}) /$ height $^{2}\left(\mathrm{~m}^{2}\right)$ ] of the cases were calculated. Patients with chronic disease, syndromic obesity, or hypothyroidism were not included in the study. Children with systemic infection or immunological disorders were excluded from the study.

The genders, ages and examination results of the cases were recorded. In the complete blood count taken at first admission in obese children, leukocyte, hemoglobin, platelet, mean platelet volume, neutrophil, and lymphocyte levels were evaluated. NLR and PLR were calculated. Fasting blood glucose and fasting insulin, serum aminotransferase values and lipid profile were recorded. Children with the LDL level $>130 \mathrm{mg} / \mathrm{dL}$ or TG level $>130 \mathrm{mg} / \mathrm{dL}$, total cholesterol level $>200 \mathrm{mg} / \mathrm{dL}$ or HDL level $<35 \mathrm{mg} / \mathrm{dL}$ were considered to be dyslipidemic (14).

Ethics committee approval of the study was obtained from the Local Ethics Committee of our hospital (No: 2018.03.1.06.028), and an informed consent form was signed in accordance with the Declaration of Helsinki.

\section{Statistical Analysis}

The data were analyzed on the computer using SPSS 25.0 (Statistical Packages of Social Sciences) program. The appropriateness of the data to the normal distribution was evaluated by the Kolmogorov-Smirnov test. Descriptive statistics were demonstrated as mean \pm standard deviation and median for continuous variables and as frequency and percentage for categorical variables. The two independent samples t-test was used to compare the normally distributed variables of two independent groups. The chi-square test was performed to analyze the difference between categorical variables. The Kruskal-Wallis test was conducted to compare the not normally distributed variables of more than two groups. The Mann-Whitney U test was used to perform the pairwise comparison of the variables that were statistically significant. It was interpreted by performing Bonferroni 
correction. In the case of $\mathrm{p}<0.05$, the difference was considered significant.

\section{Results}

While dyslipidemia was detected in $99(47.82 \%)$ of the 207 cases diagnosed with obesity, dyslipidemia was not detected in 108 cases $(52.18 \%)$.

The mean age of obese patients with dyslipidemia was $13.39 \pm 1.28$ years and the mean age of obese subjects without dyslipidemia was $13.49 \pm 1.20$ years. The mean BMI of the group with dyslipidemia was $31.48 \pm 1.81 \mathrm{~kg} /$ $\mathrm{m}^{2}$, and the mean BMI of the group without dyslipidemia was $31.44 \pm 1.79 \mathrm{~kg} / \mathrm{m}^{2}$, and no significant difference was determined between the two groups $(\mathrm{p}=0.872$ ).

The mean systolic blood pressure (SBP), mean diastolic blood pressure (DBP) and mean fasting insulin of the dyslipidemic group were found to be statistically significantly higher compared to those of the group without dyslipidemia (Table 1).

Table 1. Clinical and laboratory findings of obese children with and without dyslipidemia

\begin{tabular}{llll} 
& $\begin{array}{l}\text { Dyslipidemia (-) } \\
\mathbf{n = 1 0 8}\end{array}$ & $\begin{array}{l}\text { Dyslipidemia (+) } \\
\mathbf{n = 9 9}\end{array}$ & $\mathbf{p}$ value \\
\hline Age & $13.49 \pm 1.20$ & $13.39 \pm 1.28$ & 0.576 \\
BMI & $31.44 \pm 1.79$ & $31.48 \pm 1.81$ & 0.872 \\
Fasting insulin & $21.11 \pm 9.56$ & $27.03 \pm 19.71$ & $0.008^{*}$ \\
SBP & $120.67 \pm 11.54$ & $128.18 \pm 14.16$ & $0.0001^{*}$ \\
DBP & $74.21 \pm 8.96$ & $78.28 \pm 9.18$ & $0.001^{*}$ \\
AST & $20.62 \pm 8.21$ & $22.51 \pm 17.71$ & 0.319 \\
ALT & $20.30 \pm 13.23$ & $22.16 \pm 11.36$ & 0.617 \\
\hline
\end{tabular}

BMI: Body mass index, SBP: Systolic body pressure, DBP: Diastolic body pressure AST: Aspartate aminotransferase, ALT: Alanine aminotransferase

*Statistical significance was defined as a $p$ value $<0.05$
The mean age of the dyslipidemic group was $13.39 \pm 1.28$ years and the mean age of the group without dyslipidemia was $13.49 \pm 1.20$ years, and the mean age of the control group was $13.26 \pm 1.54$ years, and there was no statistically significant difference between the mean ages of all three groups $(\mathrm{p}=0.365)$.

While the mean leukocyte and platelet counts were determined to be statistically significantly higher in obese children with and without dyslipidemia compared to the control group ( $\mathrm{p}=0.037, \mathrm{p}=0.0001)$, the mean lymphocyte count was found to be statistically significantly lower $(\mathrm{p}=0.007)$.

The mean PLR of the dyslipidemic group was $112.75 \pm 39.11$, the mean PLR of the group without dyslipidemia was 104.78 \pm 31.38 , and the mean PLR of the control group was $110.20 \pm 39.35$, and no statistically significant difference was observed between the mean PLRs of the groups $(\mathrm{p}=0.353)$. The mean NLR was $1.52 \pm 0.69$ in the dyslipidemic group, $1.66 \pm 0.81$ in the group without dyslipidemia, and $1.72 \pm 1.26$ in the control group. There was no statistically significant difference between the mean NLRs of all three groups $(\mathrm{p}=0.295)$ (Table 2).

\section{Discussion}

Obesity is the excessive accumulation of fat in the body over acceptable measurements (15). Childhood obesity has an increasing prevalence throughout the world (16). The fact that morbidity and mortality in adulthood increase in individuals who have been obese in childhood and that $50 \%$ of those who have been obese in adolescence are obese in adulthood make obesity a significant health problem (17).

Table 2. Hemogram parameters of obese children with and without dyslipidemia and control group

\begin{tabular}{|c|c|c|c|c|c|c|c|}
\hline & $\begin{array}{l}\text { Dyslipidemia (-) I } \\
(n=108)\end{array}$ & $\begin{array}{l}\text { Dyslipidemia (+) II } \\
(n=99)\end{array}$ & $\begin{array}{l}\text { Control III } \\
(n=50)\end{array}$ & $p$ value & $\begin{array}{l}\text { I-II } \\
\text { p value }\end{array}$ & $\begin{array}{l}\text { I-III } \\
\text { p value }\end{array}$ & $\begin{array}{l}\text { II-III } \\
\text { p value }\end{array}$ \\
\hline Age & $13.49 \pm 1.20$ & $13.39 \pm 1.28$ & $13.26 \pm 1.54$ & 0.365 & - & - & - \\
\hline Leukocyte & $8.60 \pm 1.94$ & $8.64 \pm 1.98$ & $7.94 \pm 12.14$ & $0.037^{*}$ & 1.000 & 0.067 & 0.052 \\
\hline Neutrophil & $4.72 \pm 1.56$ & $4.51 \pm 1.51$ & $4.31 \pm 1.73$ & 0.100 & - & - & - \\
\hline Lymphocyte & $3.03 \pm 0.79$ & $3.10 \pm 0.67$ & $6.76 \pm 28.76$ & $0.007^{*}$ & 0.863 & 0.059 & $0.005^{*}$ \\
\hline Hemoglobin & $13.41 \pm 1.19$ & $13.64 \pm 1.07$ & $13.03 \pm 1.80$ & 0.189 & - & - & - \\
\hline MPV & $9.18 \pm 1.64$ & $9.06 \pm 1.66$ & $8.42 \pm 2.15$ & 0.053 & - & - & - \\
\hline Platelet & $300.19 \pm 64.84$ & $334.68 \pm 81.43$ & $282.89 \pm 62.42$ & $0.0001^{*}$ & $0.010^{*}$ & 0.536 & $0.001 *$ \\
\hline PLR & $104.78 \pm 31.38$ & $112.75 \pm 39.11$ & $110.20 \pm 39.35$ & 0.353 & - & - & - \\
\hline NLR & $1.66 \pm 0.81$ & $1.52 \pm 0.69$ & $1.72 \pm 1.26$ & 0.295 & - & - & - \\
\hline
\end{tabular}

MPV: Mean platelet volume, PLR: Platelet-lymphocyte ratio, NLR: Neutrophil-lymphocyte ratio

*Statistical significance was defined as a $p$ value $<0.05$ 
With the increasing prevalence of obesity, the incidence of many health problems such as cardiovascular diseases, hypertension, type 2 diabetes, and dyslipidemia is gradually increasing (3). Dyslipidemia that accompanies obesity is a significant risk factor for atherosclerotic diseases in adulthood (18). Dyslipidemia observed in obese children is explained by the lipolysis of visceral fat cells and by the increase in fatty acids produced as a result of this. In the study by Özer et al. (19), dyslipidemia was determined at a rate of $39 \%$. Atabek et al. (20) found the frequency of dyslipidemia to be $47.3 \%$. In our study, the rate of dyslipidemia was determined to be $47.82 \%$ in accordance with the literature.

In a community-based epidemiological study, people who were lost due to accidents or suicides were evaluated, and it was demonstrated that the fat lines were in $50 \%$ of the children and $85 \%$ of the adults and the formation of fibrous plaque increased with age (in $8 \%$ of the deceased children and in $69 \%$ of adults), and the presence of these lesions was found to be correlated with the elevation of total cholesterol, LDL, TG level, blood pressure, and body mass index (21). There is a close relationship between dyslipidemia and insulin resistance since insulin plays a controlling role in the elimination of blood TGs and the release of free fatty acids from adipose tissue, by activating the lipoprotein lipase (22). The incidence of hypertension in obese children is significantly higher than in normal weight children (23). In our study, we found out that SBP, DBP, and fasting insulin levels were higher in obese individuals with dyslipidemia compared to obese individuals without dyslipidemia.

Obesity itself is a chronic inflammatory process (24). Inflammatory cells infiltrate the adipose tissue in obese individuals, and these inflammatory cells and fat cells cause a low level of chronic systemic inflammation by producing cytokines $(2,6,7)$. NLR, considered to be an indicator of subclinical inflammation, is an indicator which is calculated by using neutrophil and lymphocyte values in the hemogram and of which popularity is increasing with each passing day (25). Increased inflammation and endothelial dysfunction play an important role in the pathophysiology of atherosclerotic cardiovascular diseases (26). Aydın et al. (27) found out that NLR was higher in obese adolescents than the healthy control group. In a study conducted on adult obese individuals, the NLR was not found to be a good indicator of inflammation (11). In our study, we did not determine a relationship between dyslipidemia and the NLR in obese children.
Apart from the antithrombotic effects of platelets, it is believed that they lead to leukocyte migration and binding to endothelial cells, by secreting proinflammatory cytokines, and thus play an important role in inflammation (28). The PLR is a parameter calculated by using platelet and lymphocyte values in the hemogram, and it is determined to be high in cardiovascular diseases and in cases that increase the risk of cardiovascular diseases (29). Aydın et al. (27) found out that the PLR in obese adolescents was not different from the healthy control group. In our study, we did not determine a relationship between the PLR and dyslipidemia in obese children.

\section{Conclusion}

In our study, in obese children there was no relationship between the NLR and PLR and dyslipidemia respectively. This may be related to the fact that our age group includes children and in this period, metabolic and cardiovascular complications and inflammation are less. The weak aspect of our study is that it is a retrospective study. Therefore, prospective studies involving more cases are required.

\section{Ethics}

Ethics Committee Approval: Ethics committee approval of the study was obtained from the Local Ethics Committee of our hospital (No: 2018.03.1.06.028)

Informed Consent: Informed consent form was signed in accordance with the Declaration of Helsinki.

Peer-review: Externally peer-reviewed.

\section{Authorship Contributions}

Surgical and Medical Practices: T.D.D., S.K., Concept: Ö.B.G., M.E., Design: Ö.B.G. M.E., Data Collection or Processing: T.D.D., S.K., Analysis or Interpretation: Ö.Y., F.M., Literature Search: Ö.B.G., T.D.D., Writing: Ö.B.G., T.D.D.

Conflict of Interest: No conflict of interest was declared by the authors.

Financial Disclosure: The authors declared that this study received no financial support.

\section{References}

1. Lee JM. Why young adults hold the key to assessing the obesity epidemic in children. Arch Pediatr Adolesc Med 2008;162:682687.

2. Das UN. Obesity: genes, brain, gut, and environment. Nutrition 2010;26:459-473. 
3. Pires A, Martins P, Pereira AM, Silva PV, Marinho J, Marques M, et al. Insulin resistance, dyslipidemia and cardiovascular changes in a group of obese children. Arq Bras Cardiol 2015;104:266-273.

4. D’Adamo E, Guardamagna O, Chiarelli F, Bartuli A, Liccardo D, Ferrari F, et al. Atherogenic dyslipidemia and cardiovascular risk factors in obese children. Int J Endocrinol 2015;2015:912047.

5. Moulin CM, Marguti I, Peron JP, Rizzo LV, Halpern A. Impact of adiposity on immunological parameters. Arq Bras Endocrinol Metabol 2009;53:183-189.

6. Sell H, Eckel J. Adipose tissue inflammation: novel insight into the role of macrophages and lymphocytes. Curr Opin Clin Nutr Metab Care 2010;13:366-370.

7. Gregor MF, Hotamisligil GS. Inflammatory mechanisms in obesity. Annu Rev Immunol 2010;29:415-445.

8. Kahraman NK, Kahraman C, Koçak FE, Coşgun S, Şanal B, Korkmaz $\mathrm{M}$, et al. Predictive value of neutrophil to lymphocyte ratio in the severity of nonalcoholic fatty liver disease among type 2 diabetes patients. Acta Gastroenterol Belg 2016;79:295-300.

9. Yoshimura A, Ohnishi S, Orito C, Kawahara Y, Takasaki H, Takeda $\mathrm{H}$, et al. Association of peripheral total and differential leukocyte counts with obesity-related complications in young adults. Obes Facts 2015;8:1-16.

10. Aydin M, Yilmaz A, Donma MM, Tulubas F, Demirkol M, Erdogan M, et al. Neutrophil/lymphocyte ratio in obese adolescents. North Clin Istanb 2015;2:87-91.

11. Bahadır A, Baltacı D, Türker Y, Türker Y, Iliev D, Öztürk S, et al. Is the neutrophil-to-lymphocyte ratio indicative of inflammatory state in patients with obesity and metabolic syndrome? Anatol J Cardiol 2015;15:816-822.

12. Chen J, Chen MH, Li S, Guo YL, Zhu CG, Xu RX, et al. Usefulness of the neutrophil-to-lymphocyte ratio in predicting the severity of coronary artery disease: a Gensini score assessment. J Atheroscler Thromb 2014;21:1271-1282.

13. Wang X, Xie Z, Liu X, Huang X, Lin J, Huang D, et al. Association of platelet to lymphocyte ratio with non-culprit atherosclerotic plaque vulnerability in patients with acute coronary syndrome: an optical coherence tomography study. BMC Cardiovasc Disord 2017; 17:175

14. Cruz ML, Goran M. The metabolic syndrome in children and adolescents. Current Diabetes Report 2004;4:53-62.

15. Mei Z, Grummer-Strawn LM, Pietrobelli A, Goulding A, Goran MI, Dietz WH. Validity of body mass index compared with other bodycomposition screening indexes for the assessment of body fatness in children and adolescents. Am J Clin Nutr 2002; 75:978985.
16. Martorell R, Kettle K, Hughes ML, Grummer-Stawn ML. Overweight and obesity in preschool children from developing countries. International Journal of Obesity 2000;24:959-967.

17. Klish WJ. Childhood obesity: pathophysiology and treatment. Acta Paediatr Jpn 1995;37:1-6.

18. American Academy of Pediatrics. National Cholesterol Education Program (NCEP): highlights of the report of the Expert Panel on Blood Cholesterol Levels in Children and Adolescents. Pediatrics 1992;89:525-584.

19. Özer S, Sönmezgöz E, Ünüvar Ş, Yllmaz R, Demir O. Obez Çocuklarda Metabolik Sendrom Sıklığı ve Bileşenlerinin Değerlendirilmesi. Çocuk Dergisi 2015;15:10-15.

20. Atabek ME, Pirgon O, Kurtoglu S. Prevalence of metabolic syndrome in obese Turkish children and adolescents. Diabetes Res Clin Pract 2006;72:315-321.

21. Newman WP 3rd, Freedman DS, Voors AW, Gard PD, Srinivasan SR, Cresanta JL, et al. Relation of serum lipoprotein levels and systolic blood pressure to early atherosclerosis. The Bogalusa Heart Study. N Engl J Med 1986;314:138-144.

22. Lewis GF, Steiner G. Acute effects of insulin in the control of VLDL production in humans. Implications for the insulin resistant state. Diabetes Care 1996;19:390-393.

23. Ahmadi A, Gharipour M, Nouri F, Kelishadi R, Sadeghi M, and Sarrafzadegan N. Association between adolescence obesity and metabolic syndrome: Evidence from Isfahan Healthy Heart Program. Indian J Endocrinol Metab 2014;18:569-573.

24. Cave MC, Hurt RT, Frazier TH, Matheson PJ, Garrison RN, McClain CJ, et al. Obesity, inflammation, and the potential application of pharmaconutrition. Nutr Clin Pract 2008;23:16-34.

25. Zahorec R. Ratio of neutrophil to lymphocyte counts-Rapid and simple parameter of systemic inflammation and stress in critically ill. Bratisl Lek Listy 2001;102:5-14.

26. Ziyrek M, Tayyareci Y, Yurdakul S, Sahin ST, Yıldırımtürk O, Aytekin S. Association of mitral annular calcification with endothelial dysfunction, carotid intima-media thickness and serum fetuin-A: an observational study. Anadolu Kardiyol Derg 2013;13:752-758.

27. Aydin M, Yilmaz A, Donma MM, Tulubas F, Demirkol M, Erdogan $\mathrm{M}$, et al. Neutrophil/lymphocyte ratio in obese adolescents. North Clin Istanb 2015;2:87-91.

28. Kaplan ZS, Jackson SP. The role of platelets in atherothrombosis. Hematology Am Soc Hematol Educ Program 2011;2011:51-61.

29. Turkmen K, Erdur FM, Ozcicek F, Ozcicek A, Akbas EM, Ozbicer A, et al. Platelet-to-lymphocyte ratio better predicts inflammation than neutrophil-to-lymphocyte ratio in end-stage renal disease patients. Hemodial Int 2013;17:391-396. 